\title{
English Language Perception and Needs for English for Specific Purpose (ESP) of 11th Grade Students at 116 State High School Ragunan
}

\author{
Lidya Pawestri Ayuningtyas \\ English Department, Faculty of Humanities, University of Indonesia \\ UI Depok Campus, West Java, 16424, Indonesia
}

Tel: 62-21-7867222 E-mail: lidya.pawestri@ui.ac.id

Received: December 19, 2014 Accepted: January 5, 2015 Published: January 6, 2015

doi:10.5296/ijele.v3i1.6878 URL: http://dx.doi.org/10.5296/ijele.v3i1.6878

\begin{abstract}
This study investigates English language perception and needs for English for Specific Purpose of 11th grade students at 116 State High School Ragunan, since the students are teenage professional athletes. The difference English need with the average high school students' need make this study significant. The school is also applying the latest Indonesian curriculum, Kurikulum 2013 which can be combined with the specific purpose of the students. The method used in this study is descriptive quantitative, using closed-questionnaire and interview. The result shows that the students' perception of English is still low in four aspects (listening, reading, writing, and speaking), but the lowest is speaking skill. It is important for the teachers to provide students with the skill they need the most and meet the change of curriculum in Indonesia.
\end{abstract}

Keywords: English language perception, English language needs, ESP, Indonesia 


\section{Introduction}

English subject is a mandatory subject in Indonesian senior high school, either in public high school or vocational high school. However, there is still a lack of study in the field of English for Specific Purpose (ESP) especially for high school students, since most of studies are undertaken for graduate or postgraduate university students, even for the professionals, as have been conducted, take for example are research studies by Algadrie (2002), Suhendi (2005), and Saragih (2014). The current condition is still in relation with Astika's research more than a decade ago, in which she stated "In spite of the increasing demand for English language teaching, this situation has not invoked sufficient research in ESP, especially the needs of various groups of learners or people who need to have sufficient command in English" (1999, p. 3).

SMAN 116 Ragunan Jakarta (116 State High School Ragunan) is a unique high school in term of its students, since all the students enrolled in the school are teenage professional athletes who often go abroad for competition or training. The high school was in the same building with SMPN Ragunan Jakarta for athletes (Ragunan Junior High School). Both schools share the same teaching staffs and principal. As a matter of fact, all Ragunan Junior High School students enter the 116 State High School Ragunan, while the high school also accepts students from other junior high schools as long as the students pass the sport test and possess high-stake achievement in sport.

Established in 1977, until now the school has accepted students from various sports; athletics, basketball, volleyball, badminton, diving, archery, gymnastics, football, tennis, table tennis, wrestling, tae kwon do, swimming and sepaktakraw ("Sejarah", n.d.). Nowadays, the school accepts students from other sport backgrounds. For example, its students also comprise from fencing, pencak silat, and squash athletes.

Unlike other Indonesia state high schools, 116 State High School Ragunan study time is less than the normal study hour, starts from 8 a.m. to 12 p.m. Before and after the school hours, students are obliged to do sport training until the evening. Thus, their study hours are reduced since they are also demanded to perform the best in sport. Teachers must face the challenge to provide good education for them, because it was one of the considerations in establishing the school ("Sejarah", n.d.). English is one of the school subjects which only being taught for half of a normal study hour compared to other public high schools. Furthermore, the pupils at least go abroad for training or competing once during their study in the school, and they also have to communicate in English.

The school has already applied the latest curriculum in Indonesia, Kurikulum 2013 (literally translated as 2013 Curriculum) for three semesters. This curriculum improves the drawbacks of its predecessor. For instance, for English subjects, the previous curriculum (Kurikulum KTSP 2006) highlighted the importance of grammar and did not emphasize the expression and spontaneity in communicating the ideas. In Kurikulum 2013, language competence is emphasized to convey ideas and the students are accustomed to express themselves with spontaneous convincing language (Kementerian Pendidikan dan Kebudayaan, 2014). 
In this curriculum, teachers act as facilitator while students have to actively participate. The curriculum also gives teachers freedom to include the cultural environment related to any field (culture, sports, arts) of the school into the syllabus. Since the culture of 116 State High School Ragunan is close to sport, it is assumed that the teachers should apply the culture into classroom in order to meet the syllabus and to provide students with their needed English skill as athletes. However, this does not happen in the school and moreover, no needs analysis has been conducted before.

This paper will discuss the students' perception of their English language ability, the specific English needs of the students, interview with two English teachers in the school to see the condition of English course, and eventually the recommendations for the teachers relating to English course

\section{Literature Review}

Graddol (2000) in Paci (2013) said that English will still be lingua franca in the next 50 years. Further, Paci (2013) also added that English language "will continue to have a strong status becoming the language of science, medicine, politics, business, internet, online communication, arts, and sports” (p. 425).

"Any course should be based on an analysis of learner need" (Hutchinson and Waters, 1987, p.53). By doing so, the teachers can support the students what they request. Not only supporting the students' need, but also needs analysis "can produce information to give feedback on the course design so that revision and improvement can be made" (Liang and Chen, 2011). In addition, it can "(E)ncouraging the course participants to start taking ownership of their course, making choices about what they want or need. ... When people feel they have some power or responsibility over what happens to them, it can really change their attitude to it" (Scrivener, 2005, p. 72). Richards (2001) in Souriyavongsa, et.al. (2013), considered that "the English language needs of students in institutions influence the learning and teaching situations". Hyland (2007) in Tseng (2014) "informs the design and development of a language program's curricula and materials and underlines the prismatic engagement of the program with occupational, academic, and professional realities".

Hutchinson and Waters (1987) then concluded that needs analysis is the most distinctive feature in ESP, thus target situation needs and learning needs must be considered important. Target situation needs are 'necessities', 'lacks', and 'wants' of the target situation. It means that before designing the syllabus, researcher has to know and understand these three aspects. Robinson (1991) in Li (2014) stated that "Target Situation Analysis (TSA) is a kind of needs analysis which mainly focuses on students' needs at the end of a language course". Learning needs, on the other hand, is "what the learner needs to do in order to learn" (p. 54). In other words, learning needs answer the 'how' question in achieving the target.

Pradhan (2013) observed the trends of ESP research and found that it "happens mostly within the overlapping domains of English Language Education for specific purposes and discourse/genre analysis" (p. 3). Hewings (2002) in Pradhan (2013) provided brief summary of ESP study that 'Needs analysis/syllabus design' topic is the third most popular research 
after 'Text/discourse analysis' and 'program description' published in Elsevier from 1980 to 2001. It is in line with what Qaddomi (2013, p.1111) stated in his paper that "During the last thirty three years there have been a huge number of studies that attempted to analyze the learners vocational or academic needs". Needs analysis plays important role to shape the English course we know nowadays.

Scrivener (2005) suggested that there are three ways to gather information about needs analysis, by writing (such as asking students to fill in questionnaire), speaking (by interviewing them), or observation in class. However, "If the learners' language level is low, many of the Needs analysis ideas could be used in their mother tongue" (Scrivener, p. 70).

\section{Method}

Kothari (2004) in Souriyavongsa et al (2013) states that "research design is needed because it facilitates the smooth operation of research". The design of this research is to analyze the students' perception of English language needs for ESP by using questionnaire. Zikmund (2000) in Khan, et.al. (2013) states that "an essential aspect of research design is the task of writing questionnaire, determining the list of questions and designing the exact format printed or written" (p.264). First, the final questionnaire was preceded by pilot questionnaire. Pilot questionnaire was given to know which questions should be included in the final questionnaire.

Then, the data will be presented by discussing part by part. Finally, the data will be discussed to see the important things that appeared in the data

\subsection{Participants}

Before disseminating the final questionnaires, the pilot questionnaires were given to 14 students two weeks prior. The final participants are 40 11th grade students of 116 State High School Ragunan. The students, even though only comprise of $33.3 \%$ of all the 11 th grade students, can give evidence of their perception of English language needs in their school. The students of 11th grade were chosen because they are the highest grade students whom the Kurikulum 2013 is applied to. So, the result of this study can be applied to the lower batches, unlike if the study conducted to 12th grade students since they still use the old curriculum, Kurikulum KTSP 2006. The highest grade was also chosen due to the maturity reason, since they already can comprehend the question items better than their lower peers.

It was not possible to make each student as the respondent, because many of them were out of town for training and doing competition for weeks. Therefore, due to the limited time, only 40 students were able to participate.

Two English teachers who teach there were interviewed in order to know their view of English subject and its relation with the new curriculum

\subsection{Materials and Procedures}

The materials are divided into two parts. The first is the pilot questionnaire. Apart from the questions of students' background, the pilot questionnaire comprise of 14 closed-questions. 
The questionnaire then was analyzed and revised to be clearer. Then, the improvement adapted the model of Diallo (2007). The final questions are 20 closed-questions. There are 4 parts of the final questionnaire. The first part asks about the basic information of the students. The second part asks about the information of the students' training and competition abroad experience. The third part is about the English perception of the students. Finally, the last part is about their future plan regarding higher study which involves their English skill and awareness.

The questionnaires were given during the class hour and it took half an hour to finish all the 20 questions. The return rate is $100 \%$, it means that all students responded all the questions. The questionnaire was in Indonesian to avoid misinterpretation.

The teachers are also interviewed using questions which also adopted by the list from Diallo's dissertation (2007) and modeled after article by Saragih (2014), but it was conditioned to meet the purpose and aim of this study. The interview was conducted in Indonesian in the same day with dissemination of the questionnaires to the students.

\section{Result}

The quantitative data is analyzed manually in order to know the percentage and each part of questions is analyzed descriptively. The analysis will further be discussed in sub results. Furthermore, the interview with the teachers is synthesized to make it comprehensive.

\subsection{Basic Information}

The first part of the questions is to know basic information/background of the students. They are initial letters of their names, gender, age, and sport. Another background to be asked are whether the students also studied in SMPN Ragunan for athletes (Ragunan Junior High School) previously and whether or not they have undertaken English course outside the formal school. The following tables show the details.

Table 1. Number of Participants According to Gender

\begin{tabular}{|l|c|c|}
\hline Gender & Number of Frequency & Percentage (\%) \\
\hline Male & 17 & 42.5 \\
\hline Female & 23 & 57.5 \\
\hline Total & 40 & 100 \\
\hline
\end{tabular}

As shown in the table above, female respondents are higher in number than their male counterparts. 
Table 2. Number of Participants According to Age

\begin{tabular}{|l|c|c|}
\hline Age & Number of Frequency & Percentage (\%) \\
\hline 15 & 10 & 25 \\
\hline 16 & 19 & 47.5 \\
\hline 17 & 11 & 27.5 \\
\hline Total & 40 & 100 \\
\hline
\end{tabular}

Respondents age range from 15 years old to 17 years old, with the highest participants are 16 years old.

The students enrolled in the school and participated in this study are from these sports; tae kwon do, wrestling, sepaktakraw, pencak silat, weight lifting, swimming, athletics, rhythmic gymnastics, archery, football, basket ball, and volley ball.

Table 3. Information of Previous Study in Ragunan Junior High School

\begin{tabular}{|l|c|c|}
\hline $\begin{array}{l}\text { Study in Ragunan Junior } \\
\text { High School }\end{array}$ & Number of Frequency & Percentage (\%) \\
\hline Yes & 22 & 55 \\
\hline No & 18 & 45 \\
\hline Total & 40 & 100 \\
\hline
\end{tabular}

Fifty five per cent student enrolled in Ragunan Junior High School, while the rest came from other junior high school.

Table 4. Information of Taking Non-formal English Course

\begin{tabular}{|l|c|c|}
\hline Take English Course & Number of Frequency & Percentage (\%) \\
\hline Yes & 6 & 15 \\
\hline No & 34 & 85 \\
\hline Total & 40 & 100 \\
\hline
\end{tabular}

Six students undertook English course studied English in the non-formal English course from 
two months to two years. This number is too little compare to those who did not take English course.

\subsection{Training and Competition Abroad Information}

From the data gathered, 22 students or equal to $55 \%$ of total respondents have never gone abroad either for training or taking part in competition. The other 18 students $(45 \%)$ have gone abroad. Of all these 18 students, 7 of them have gone abroad once, 8 of them have gone abroad twice, and 3 of them have gone abroad more than twice.

Total days spent abroad ranged from 4 days to three weeks. Popular destinations for training and doing competition in 116 State High School Ragunan are ASEAN countries, such as Singapore, Malaysia, Thailand, and Vietnam. China is the only Asian country as the destination, answered by 3 students. Beside Asia, another continent is Australia, which is only answered by one respondent. The most popular destination is Thailand, answered by 9 respondents, and both Malaysia and Singapore, answered by 5 students for each. Only students from tae kwon do, swimming, rhythmic gymnastics, archery, wrestling, pencak silat, football, basket ball, and athletics have gone abroad.

Information about English language usage inside and outside the training program and competition is presented by the table below.

Table 5. Usage of English Language Inside the Training and Competition

\begin{tabular}{|l|c|c|}
\hline $\begin{array}{l}\text { Usage of English Language } \\
\text { Inside the Program }\end{array}$ & Number of Frequency & Percentage (\%) \\
\hline Yes & 14 & 77.8 \\
\hline No & 4 & 22.2 \\
\hline Total & 18 & 100 \\
\hline
\end{tabular}

Table 6. Usage of English Language Outside the Training and Competition

\begin{tabular}{|l|c|c|}
\hline $\begin{array}{l}\text { Usage of English Language } \\
\text { Outside the Program }\end{array}$ & Number of Frequency & Percentage (\%) \\
\hline Yes & 16 & 88.9 \\
\hline No & 2 & 11.1 \\
\hline Total & 18 & 100 \\
\hline
\end{tabular}

From Table 5 and Table 6, we can see that most students went abroad use English to communicate inside and otside the training and competition. 


\subsection{English Perception of Students}

Most of the eighteen students who have experience in training and taking part in competition abroad feel that their English skill is not enough in doing the program, and in communicating with the local people in the countries where they did the training and competition.

However, all of the 40 students feel the need to improve their English skill in their school. Thirty six students $(90 \%)$ answered that English skill is important for their study and their sport activity. Thirty one students think that English course in the school has not yet sufficient in improving their English ability.

Next, their perception of English in four aspects (writing, reading, speaking, and listening) is shown in the table below. The scale is using Likert's type, with 1 is very poor, 2 poor, 3 moderate, 4 good, and 5 very good.

Table 7. Perception of English Skill in Four Aspects

\begin{tabular}{|l|c|c|c|c|c|}
\hline \multicolumn{1}{|c|}{ Skill } & $\mathbf{1}$ & $\mathbf{2}$ & $\mathbf{3}$ & $\mathbf{4}$ & $\mathbf{5}$ \\
\hline Writing & 1 & 13 & 21 & 4 & 1 \\
\hline Reading & 2 & 15 & 16 & 6 & 1 \\
\hline Speaking & 7 & 22 & 9 & 2 & 2 \\
\hline Listening & 3 & 16 & 14 & 5 & 4 \\
\hline Total & 13 & 66 & 60 & 17 & 4 \\
\hline
\end{tabular}

As we can see from Table 7, students mostly perceive their language ability as 'poor' and 'moderate' respectively, then followed by 'good' and 'very poor'. The lowest is 'very good' category.

However, the lowest language perception is 'Speaking' skill with 7 students perceive their speaking skill is 'very poor'. This is the highest in 'very poor' category. Other 22 students think that their 'speaking' ability is 'poor'. This is also the lowest in 'poor' category. Only 9 and 2 students consider that their Speaking ability is 'moderate' and 'good'. However, none of them think that their speaking ability is 'very good'.

Writing, reading, and listening skill are somewhat similar. Even though the highest numbers are in 'poor' and 'moderate' categories, the numbers do not differ much. These three language skills also add up students' number in 'very good' category, even though only one, one, and two students for writing, reading, and listening.

In relation to this, 23 students $(57.5 \%)$ regard Speaking skill as the skill they want to learn the most. It is followed by 9 students who chose reading skill. Writing and listening were chosen by 4 students for each. 
Also, 37 students agree that they need to do more conversation practice during English course at school. They also agree if the topic is related to the training and competition abroad to support them as athletes.

The next items uncover the fact that 31 students (77.5\%) do self-improvement of their English language ability. The most popular way of them in increasing their skill is by listening to English songs, chosen by 21 students (55\%). This is followed by watching English-language movies, speaking in English, and finally by reading printed media (books, newspapers, magazines) in English.

\subsection{Future Plans}

A total of 38 students answered that they are planning to continue to higher education such as university, polytechnic, and academy after graduation. However, only 35 of them are aware that English language will be tested in university entrance selection test.

\subsection{Interview with Two Teachers}

Two teachers were interviewed in order to know the condition in 116 State High School Ragunan regarding to English subject. All of them started teaching in the beginning of 2000s, and they teach from the 7 th grade until the 12th grade. They admitted that the lack of teaching staff influenced the quality in teaching English. They also agreed that the limited time was also important reason why teaching English in the school was not optimum. Another reason was that the students already tired when studying, because their training consumed much of their energy for studying. Also, students often take much time to do the training or competition out of town or abroad, so they cannot attend the class full time.

Even though the teachers realized that their students need English skill apart from the general English they taught inside the classroom which still sticks to the syllabus (Rencana Pelaksanaan Pembelajaran/RPP), they still can apply the modification to the syllabus. They wanted to apply the culture of the school inside the classroom, especially when they do speaking skill. Both of the teachers have not taken English for Specific Purpose training, but they consider it as important. It is because the fact in the field that their students need English for sport.

The application of Kurikulum 2013 also gives positive impacts, since it allows teacher to modify the lesson unlike the previous curriculum. Also, it demands students to be more active in the classroom, so they can do more speaking practice to make them fluent in English.

\section{Discussion}

The fact that only students from several sports go abroad, must be underlined. This is important to notice that not all students from every sport are going to do training and competition in other countries. However, because the ratio of students who go abroad and do not go is almost 1:1, it is also crucial to provide the same English skill to them. It is because they also do training and join international competition at Home, and their counterparts are also athletes from other countries. 
The skill they want to master most is speaking skill. This is no wonder given the fact that they have to communicate with foreigners. Moreover, their destination countries such as Singapore, Malaysia, and Australia consider English as the formal language in the country albeit there are other formal languages.

The students also were given question about their future plan. This is important, because if the students already know their plan, it will motivate them to learn a skill to pursue their plan. The fact that all 40 respondents answered that they need to improve their English ability in their school but only 31 of them think that school has not yet sufficient in improving their English ability, also must be taken into account. Thus, school must provide the most effective way to meet the students' need.

It is good to find that students also improve their English language skill outside the classroom by using some media. However, their speaking skill is the most crucial part, because it is regarded as the lowest skill, also as the skill they want to learn most. Students' awareness that English will be tested in university entrance exam is also a good sign, because if they already know what they will face ahead, they will be more prepared to overcome it.

English for Specific Purpose is the solution for the students' problem. For example, in the chapter talking about hobby, teachers may give examples about some hobbies that are related to sport activities. Teachers can also provide the students by giving assignments that are in line with their activities such as training and competition. As the curriculum already uses the information technology such as internet, learning English that related to sports can be done in an updated environment.

\section{Conclusion}

This study aim is to see how 11th grade students of 116 State High School Ragunan perceive their English language ability and needs to design the most suitable syllabus and course material for the specific purpose in Sport. We can see that they really need the speaking skill and have awareness of how they should improve their English. They also believe that English will help them through their sport activities and studying. With this in mind, we can assume that they have strong willingness in learning, so the present situation will be helpful in designing course syllabus and course materials.

The most recent news in Indonesia regarding Kurikulum 2013 is that it will be dropped in January 2015. However, for the schools who already applied the curriculum for three semesters such in 116 State High School Ragunan, Anies Baswedan, The Culture and Elementary and Secondary Education Minister, stated "6,221 schools that have implemented the curriculum for the past three semesters could continue according to new guidelines" (Budiari, 2014). Thus, this research result can help in designing the course materials that are suitable for the students of 116 State High School.

Further studies on the students' English needs should be conducted in order to adjust the changing and always developing curriculum in Indonesia. 


\section{Pedagogical Implication}

The syllabus used in an educational institution has to answer the students' needs. Although the English subject syllabus used in 116 State High School Ragunan is in general English and follow the Kurikulum 2013, the needs of its students are quite different with other high school students in general. The culture of the school which is strongly related to sport must be considered and should be the advantages in formulating the syllabus. For example, in one chapter of the book used in the school, there is a speaking section about daily activities. Teacher can give useful expressions that relate to sport activities, because it is the specific need of the students. Teachers can also ask the students to actively participate in class by asking them to bring any short articles about their sport and in turn they can talk about it in small groups. As speaking skill is strongly emphasized in the curriculum, teachers in the school only need to combine the school culture to the present curriculum.

\section{Acknowledgement}

The author would like to express gratitude to Beasiswa Unggulan of Ministry of Education and Culture which supports the financial during the study in English Literature Bachelor Degree for four years and in conducting this research, the English teachers and the respondents at 116 Ragunan High School, and Ms. Harwintha Yuhria Anjarningsih for the valuable suggestions.

\section{References}

Algadrie, L. (2002). Needs Analysis: Strategic Issue on the Teaching of English for Specific Purposes for the Study of Sciences and Technology. TEFLIN, 13(1).

Astika, C. (1999). The Role of Needs Analysis in English for Specific Purposes. TEFLIN, $10(1)$.

Budiari, I. (2014, December 7). Anies nixes much-maligned 2013 curriculum. The Jakarta Post, p. 2.

Diallo, M. S. (2007). English Needs Analysis of Science and Technology Students at Cheikh Anta Diop University in Dakar (UCAD) (Doctoral Dissertation, University of Maryland Baltimore County, 2007).

Kementerian Pendidikan dan Kebudayaan. (2014). Paparan Menteri Pendidikan dan Kebudayaan RI- Press Workshop: Implementasi Kurikulum 2013. Jakarta. http://kemdikbud.go.id/kemdikbud/node/2070

Khan, Z. A., Syah, S. K., Khan, R. A., \& Khan, R. A. (2013). Designing an English Language Course: A Case Study of LLB (H) Students at Govt. College University Faisalabad-Pakistan. Interdisciplinary Journal of Contemporary Research in Business, 4(11), 259-286.

Li, J. (2014). Needs Analysis: An Effective Way in Business English Curriculum Design. Theory and Practice in Language Studies, 4(9), 1869-1874. http://dx.doi.org/10.4304/tpls.4.9.1869-1874. 
Liang, A., \& Chen, Y. (2011). A Case Study of College English Curriculum Design Under the Social Needs Analysis. Studies in Literature and Language, 3(3), 1-5. http://dx.doi.org/10.3968/j.sll.1923156320110303.7z0128

Paci, M. (2013). Needs Analysis and Environment Analysis: Designing and ESP Curriculum for the Students of the Polytechnic University of Tirana. Journal of Educational and Social Research, 3(7), 425-430. http://dx.doi.org/10.5901/jesr.2013.v3n7p425

Pradhan, A. (2013). English for Specific Purposes: Research Trends, Issues and Controversies. English for Specific Purposes World, 14(40).

Qaddomi, H. A. (2013). English for Specific Purposes in Palestinian Context: Determining EFL Cadets' Needs at Al Istiqlal University. Theory and Practice in Language Studies, 3(7), 1110-1122. http://dx.doi.org/10.4304/tpls.3.7.1110-1122

Saragih, E. (2014). Designing ESP Materials for Nursing Students Based On Needs Analysis. International Journal of Linguistics, 6(4), 59-70. http://dx.doi.org/10.5296/ ijl.v6i4.5983

Sejarah. (n.d.). http://skoragunan.sch.id/profil/sejarah

Souriyavongsa, T., Abidin, M. J. Z, Sam, R., Mei, L. L., \& Aloysius, I. B. (2013). Investigating Learning English Strategies and English Needs of Undergraduate Students at the National University of Laos. English Language Teaching, 6(10), 57-71. http://dx.doi.org/10.5539/elt.v6n10p57

Suhendi, A. (2005). English Language Learners at The Faculty of Agriculture, Islamic University of North Sumatra-Indonesia (Magister Dissertation, Universiti Sains Malaysia, 2005).

Tseng, M. (2014). Language Needs Analysis for Taiwanese Arts Students: What do young artists need to know? Journal of Arts, Science \& Commerce, 5(1), 25-36.

\section{Copyright Disclaimer}

Copyright for this article is retained by the author(s), with first publication rights granted to the journal.

This is an open-access article distributed under the terms and conditions of the Creative Commons Attribution license (http://creativecommons.org/licenses/by/3.0/). 